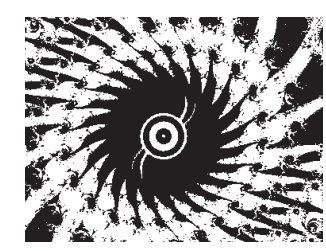

\title{
PREDRASUDE U DJEČJOJ DOBI: PROVJERA DVIJU SKALA SOCIJALNE DISTANCE
}

Jelena MARIČIĆ

Institut društvenih znanosti Ivo Pilar, Zagreb

Željka KAMENOV

Filozofski fakultet, Zagreb

Kristina HORVAT

Osnovna škola Orehovica, Orehovica

UDK: 316.647.8-053.5(497.5Zagreb)

Izvorni znanstveni rad

Primljeno: 26. 10. 2010.

Rad je proizašao iz rada na znanstvenom projektu "Društveni stavovi i međugrupni odnosi u hrvatskom društvu", provođenog uz potporu

Ministarstva znanosti, obrazovanja i športa Republike Hrvatske.
Da bi se istražile dječje predrasude, 311 učenika i učenica petih razreda iz šest zagrebačkih osnovnih škola odgovaralo je na dvije skale socijalne distance za djecu. Jednom skalom mjerila se spremnost i na udalienije i na bliskije oblike kontakta (od života u istom gradu do bliskoga prijateljstva) s djecom koja imaju neko specifično obilježje, a drugom samo spremnost na bliske oblike kontakta s tom djecom, odnosno spremnost na zajedničke aktivnosti u slobodno vrijeme. Ciljne skupine bile su slijepa djeca, djeca koja se kreću u invalidskim kolicima, pretila djeca te djeca romske nacionalnosti. Uz zadavanje jednog faktora sve su čestice na pojedinim skalama pokazale zadovoljavajuće visoko zasićenje na istom faktoru. Djeca na obje skale iskazuju najvišu socijalnu distancu prema romskoj djeci, dok su socijalne distance prema pripadnicima ostalih triju skupina približno jednake. Dječaci iskazuju veće neprihvaćanje svih skupina nego djevojčice. Pronađena je razmjerno visoka povezanost među socijalnim distancama iskazanima prema istim skupinama na različitim instrumentima. Nalazi općenito upućuju na diečju sklonost odbacivanju pripadnika određenih skupina te upozoravaju na važnost intervencija za suzbijanje predrasuda u predadolescenciiji.

Ključne riječi: dječje predrasude, socijalna distanca, socijalno odbacivanje, osobe s invaliditetom, pretili, Romi

Jelena Maričić, Institut društvenih znanosti Ivo Pilar, Marulićev trg 19/1, p. p. 277, 10001 Zagreb, Hrvatska. E-mail: Jelena.Maricic@pilar.hr 
Djetinjstvo je najprimjerenije razdoblje za suzbijanje predrasuda, a provođenje teorijski utemeljenih istraživanja važan je element u kreiranju učinkovitih intervencija s tim ciljem. Dvije dominantne teorije na području dječjih predrasuda jesu socijalnokognitivna teorija razvoja predrasuda (Aboud, 1988.) i razvojna teorija socijalnog identiteta (Nesdale, 1999.). Prema socijalnokognitivnoj razvojnoj perspektivi (Aboud, 1988.), dječje su predrasude u najvećoj mjeri posljedica nedovoljno razvijenih kognitivnih sposobnosti. Za razliku od Aboud (1988.), koja tvrdi da se predrasude smanjuju u dobi od 7 godina kao rezultat kognitivnih dostignuća, Nesdale (1999.) navodi da se $\mathrm{u}$ toj dobi predrasude tek kristaliziraju. Potonja autorica navodi da, iako sociokognitivni procesi utječu na razvoj ili suzbijanje predrasuda, ipak su socijalni procesi ti koji dominiraju. Predrasuda ne znači samo manje sviđanje pripadnika vanjske nego unutrašnje grupe već i izraženo nesviđanje ili čak mržnju prema pripadnicima vanjske grupe (Nesdale, 1999.). Ako ljudi u djetetovoj okolini dijele i jasno izražavaju svoje predrasude, one postaju društvena norma, pa se očekuje da će ih i djeca prihvatiti (Nesdale, 1999.). Dječji načini izražavanja predrasuda mogu biti puka imitacija (Aboud i Levy, 2000.), no češće se radi o činjenici da djeca preuzimaju takve stavove kao svoje zbog toga što vide sebe kao člana skupine koja ima određeni set uvjerenja (Fishbein, 2002.). Djeca uglavnom do 11 godina internaliziraju norme o (ne)izražavanju predrasuda (Rutland i sur., 2005.).

Iako je svim predrasudama zajedničko to da su "neopravdani negativni stavovi prema skupini ljudi zbog njihove pripadnosti određenoj skupini" (Fishbein, 2002., str. 4-5), one se mogu razlikovati u nekoliko aspekata. Primjerice, predrasude prema osobama s invaliditetom, prema pretilim osobama i prema Romima povezane su s raznim stereotipima i emocijama te s raznim normama o (ne)izražavanju predrasuda.

Osobe bez invaliditeta često doživljavaju one s invaliditetom na stereotipan način; pripisuju im da su inferiorne, manje inteligentne te da preferiraju društvo drugih osoba s invaliditetom (Henderson i Bryan, 1997.). Hanna i Graff (1977., prema Shapiro, 1999.) rabe pojam "proširivanja stigme" kao uobičajenu tendenciju percipiranja osoba s invaliditetom kao oštećenih $u$ većem broju aspekata, primjerice u pogledu osobnosti, inteligencije i fizičkih sposobnosti koje nemaju veze sa samim oštećenjem. Smith i Williams (1999.) pronašli su da je pojava "proširivanja stigme" najveća kod predškolaca, dok se u školskoj dobi donekle smanjuje. Stereotipi o pretilima glase da su lijeni, nedisciplinirani i skloni prejedanju (npr., Harris i sur., 1982.), a o Romima da su lijeni, prljavi i nekulturni (Grgić, 2006.). 
DRUŠ. ISTRAŽ. ZAGREB GOD. 21 (2012), BR. 1 (115)

STR. 137-158

MARIČIĆ, J., KAMENOV, Ž., HORVAT, K.: PREDRASUDE U
Što se tiče emocionalnog aspekta predrasuda, prema osobama s invaliditetom česti su osjećaji sažaljenja i divljenja (npr. Norden, 1994.; Shapiro, 1999.) te nelagode u kontaktu (Leutar i Štambuk, 2006.), koju navode već i djeca (Leutar, 2003.). Emocije prema pretilim osobama manje su jasne, no vjerojatno se radi o gađenju i o ljutnji (Crandall i sur., 2009.), dok se uz Rome često vežu emocije ljutnje i prezira.

"Prema normativnim objašnjenjima, predrasude su posljedica socijalnih normi koje unutar kulture određuju na koji je način potrebno percipirati i ponašati se prema pripadnicima određenih skupina" (Fishbein, 2002., str. 22). Za normu da je prihvatljivo izraziti predrasudu primjer mogu biti predrasude prema Romima, koje su u hrvatskom društvu najčešće relativno eksplicitno izražavane (npr. Hrvatić, 1996.). Također, predrasude prema pretilima najčešće se izražavaju posve otvoreno (Crandall i sur., 2009.), iako treba napomenuti da se radi o nalazima stranih istraživanja. Normama vezanima uz osobe $s$ invaliditetom ne potiče se otvoreno iskazivanje predrasuda prema njima. To ipak ne znači da su te norme primjerene; one se, naime, često temelje na sažaljenju (Shapiro, 1999.).

Pojam blizak predrasudama jest stigmatizacija. Stigma je socijalna konstrukcija koja uključuje barem dvije temeljne sastavnice, a to su prepoznavanje različitosti utemeljeno na nekoj istaknutoj karakteristici i obezvređivanje osobe (Dovidio i sur., 2000.). Stigmatizacija može biti povezana s tjelesnim oštećenjem (npr. sljepoćom ili tjelesnim invaliditetom), sa "sramotnom" individualnom karakteristikom (npr. pretilošću) ili s pripadanjem nepoželjnoj etničkoj skupini, odnosno "plemenu" (npr. romskoj etničkoj skupini) (Dovidio i sur., 2000.).

Jedan od oblika izražavanja predrasuda jest odbijanje kontakta s pripadnicima različitih skupina. Ako osoba odbija bilo kakav, pa čak i najudaljeniji, kontakt s pripadnikom neke skupine, to pokazuje da su predrasude prema toj skupini vrlo izražene. Ako odbija samo najbliskije oblike kontakta, njezine su predrasude manje izražene, no i dalje mogu biti vrlo povređujuće za žrtvu predrasude, pa i za samu osobu koja se ponaša na takav način. Bogardus je (1925.) konstruirao instrument kako bi izmjerio ovu pojavu preko konkretnih odnosa u koje pripadnici različitih grupa mogu stupati. On je prvi put definirao sedam takvih odnosa, a skala se i dalje razvijala. Socijalna distanca smatra se najbližom ponašajnoj sastavnici stava, koja može, ali i ne mora, biti u skladu s emocionalnom i kognitivnom sastavnicom. Na mjerenje, ali i na stvaranje i održavanje socijalne distance, utječu: 1) opći principi kognitivnoga funkcioniranja, 2) sociodemografska obilježja pojedinca i 3) faktori koji su posljedica individualne motivacije i osobnih karakteristika (Hill i sur., 1989.). 
DRUŠ. ISTRAŽ. ZAGREB GOD. 21 (2012), BR. 1 (115)

STR. 137-158

MARIČIĆ, J., KAMENOV, Ž., HORVAT, K.: PREDRASUDE Ü.
Ovako se najčešće ispituje etnička distanca, no uz odgovarajuću modifikaciju, Bogardusova skala može se primijeniti na ispitivanje socijalne distance prema bilo kojoj skupini osoba. Primjerice, Jokić-Begić i sur. (2005.) provele su istraživanje o stigmatizaciji duševno bolesnih osoba te su, među ostalim, primijenile skalu socijalne distance. Budući da takve osobe najčešće nisu odbačene u manje bliskim oblicima kontakta (npr. kao sugrađani), nego se problem njihove stigmatizacije najčešće odnosi na sferu bliskijih kontakata (prijateljstva, obiteljski i partnerski odnosi), za potrebe tog istraživanja je konstruirana skala koja se odnosila samo na potencijalno (ne)prihvaćanje $\mathrm{u}$ bliskim odnosima.

Iskustva odbacivanja mogu na djecu ostaviti velike posljedice, jer ona tek formiraju sliku o sebi. Osamljena djeca često imaju nisko samopoštovanje te su pojačano anksiozna i depresivna (McWhirter, 1990.). Budući da su djeci vrlo relevantne aktivnosti koje provode u slobodno vrijeme i u kojima imaju izbor s kim će ih provoditi, primjerenim nam se činilo ispitati njihovu spremnost za takvim tipom aktivnosti s djecom s određenim obilježjima, a time neizravno i vjerojatnost da će djeca iz različitih skupina biti žrtve vršnjačkog odbacivanja.

Nedostatak većine istraživanja dječjih predrasuda jest taj što se u njima primjenjuje samo jedna mjera ili se ispituju predrasude prema samo jednoj grupi (Powlishta i sur., 1994.), pa je stoga teško uspoređivati različite mjere i predrasude vezane uz različita obilježja. Istraživanje Powlishte i suradnica (1994.) pronađeno je kao jedino koje se koristi i različitim mjerama i odnosi se na različite skupine. Kao što se vidi, potonje istraživanje provedeno je prije više od 15 godina. Valja također napomenuti da se samo malen broj hrvatskih istraživanja bavi temom dječjih predrasuda (npr. Čorkalo Biruški i Ajduković, 2008.; Leutar, 2003.), a ni u objavljenim hrvatskim radovima koji se bave populacijom odraslih nikada se istodobno ne ispituju i nacionalne i etničke predrasude (npr. Banovac i Boneta, 2006.; Čorkalo i Kamenov, 2003.; Kamenov i Čorkalo, 1997.) i predrasude prema osobama s različitim tipovima invaliditeta (npr. Jokić-Begić i sur., 2005.; Leutar i Štambuk, 2006.). Oskudnost istraživanja na području dječjih predrasuda te predrasuda prema različitim skupinama možemo shvatiti kao poticaj za istraživanja na tom području. Stoga je cilj ovog istraživanja konstruirati i provjeriti dva tipa skala socijalne distance za djecu te ispitati dječju sklonost (ne)prihvaćanju pripadnika različitih skupina. Među specifičnim ciljevima jest utvrđivanje faktorske strukture i pouzdanosti skala socijalne distance. Također, u radu će se nastojati utvrditi dječja sklonost (ne)prihvaćanju vršnjaka koji se kreću u invalidskim kolicima te slijepih, pretilih i vršnjaka romske nacionalnosti, pri čemu se pretpostavlja da će djeca romske nacionalnosti zbog normi, 
stereotipa i emocija vezanih uz njih biti izložena najvećem odbacivanju. Uz to, u radu će se ispitati spolne razlike u socijalnoj distanci prema vršnjacima s navedenim obilježjima, pri čemu se, na temelju ranijih istraživanja (npr. Hazzard, 1983. Mihić i Mihić, 2003.; Powlishta i sur., 1994.) pretpostavlja da će djevojčice iskazivati manju socijalnu distancu od dječaka.

\section{METODA}

\section{Sudionici}

\section{Postupak}

\section{Instrumentarii}

Sudionici istraživanja $(\mathrm{N}=311)$ bili su učenici petih razreda šest zagrebačkih osnovnih škola, za čije su sudjelovanje roditelji dali suglasnost. Škole su se nalazile u raznim dijelovima grada, pa su uzorak činila djeca iz obitelji vrlo različitih socioekonomskih statusa. Analizom varijance provjereno je postoje li razlike među školama, pa iako su vidljive manje razlike $u$ socijalnoj distanci prema pojedinim skupinama, nije pronađeno da su djeca u nekim školama općenito sklona iskazivanju veće socijalne distance nego u drugima.

U uzorku je bilo 161 djevojčica i 150 dječaka, ni jedan od ispitivanih razreda ni trenutačno ni ranije nije polazilo slijepo dijete, dijete $\mathrm{u}$ invalidskim kolicima ili dijete romske nacionalnosti, što je prije ispitivanja provjereno s razrednicima ili stručnim suradnicima. Neki od sudionika bili su lagano pretili, no ni u jednom razredu nije primijećeno izrazito pretilo dijete.

Nakon kontaktiranja s ravnateljem i/ili stručnim suradnikom škole i objašnjenja načina te svrhe istraživanja, dogovoreni su termini istraživanja u pojedinim razrednim odjeljenjima te su istraživači zamolili razrednike ili stručne suradnike da do tada prikupe roditeljske suglasnosti. Ispitivanje je provedeno grupno, tijekom redovite nastave, a trajalo je približno 30 minuta po razredu.

$\mathrm{U}$ dijelu istraživanja koji je prikazan $\mathrm{u}$ ovome radu primijenjena su dva tipa skala socijalne distance te su postavljena pitanja o (ne)prihvaćanju pripadnika četiriju skupina. Prvu skalu nazvali smo "klasičnom" skalom socijalne distance, a drugu skalom socijalne distance vezane uz načine provođenja slobodnog vremena.

Ispitivan je dječji odnos prema pripadnicima četiriju skupina, a to su slijepa djeca, djeca koja se kreću u invalidskim kolicima, pretila djeca (nazvana "djeca koja imaju previše kilograma") i romska djeca. Djeci je dana sljedeća uputa: "Djeca mogu biti različito bliska s drugima. $S$ nekom su djecom sprem- 
DRUŠ. ISTRAŽ. ZAGREB GOD. 21 (2012), BR. 1 (115)

STR. 137-158

MARIČIĆ, J., KAMENOV, Ž., HORVAT, K.: PREDRASUDE U.. na biti prijatelji, dok drugu jedva podnose u svojoj blizini. Molimo te da razmisliš bi li ti prihvatio dječaka/djevojčicu iz određene grupe u svakom od navedenih odnosa." Prije svake pojedine skale socijalne distance bilo je navedeno: "Molimo te da znakom + označiš odnos koji bi prihvatio sa X (npr. dječakom koji se kreće u invalidskim kolicima), a znakom - da označiš odnos koji ne bi prihvatio sa X." Dječacima je pri primjeni skale postavljano pitanje bi li prihvatili dječaka iz određene skupine, a djevojčicama bi li prihvatile djevojčicu. Djeca su prvo odgovarala na "klasične" skale socijalne distance, a potom na skale socijalne distance vezane uz načine provođenja slobodnog vremena prema svim četirima skupinama. Redoslijed skupina unutar svake škole bio je isti, no razlikovao se, odnosno bio je rotiran, među školama. Skupine su kod oba tipa skala socijalne distance bile poredane istim redoslijedom.

"Klasična" skala socijalne distance formirana je na temelju skale Mihića i Mihić (2003.), uz isključivanje jedne i dodavanje dviju čestica te u konačnici sadrži 7 čestica, poredanih po očekivanom stupnju bliskosti. Budući da smo se u istraživanju željeli usmjeriti samo na odbacivanje vršnjaka, isključili smo česticu "da ti bude učiteljica". Također, budući da smo željeli malo podrobnije ispitati spremnost na bliskije oblike kontakta, dodali smo dvije čestice, a to su "da ide u tvoj razred" te "da zajedno s tobom radi neki zadatak za školu". Ukupni rezultat može biti formiran kao broj različitih oblika kontakta koji nisu prihvatljivi, pa 0 upućuje na potpuno prihvaćanje djece iz određene skupine, a 7 na potpuno neprihvaćanje djece iz određene skupine.

Za potrebe istraživanja konstruirana je i Skala socijalne distance vezane uz načine provođenja slobodnog vremena, kako bi se ispitala sklonost suptilnijim oblicima isključivanja, odnosno diskriminiranja pripadnika pojedinih skupina. U svrhu konstrukcije instrumenta provedeno je pismeno ispitivanje djece koja polaze dva peta razreda u jednoj zagrebačkoj osnovnoj školi. Postupak je proveden tako da su djeci, jedno po jedno, postavljena tri pitanja, a ona su svoje odgovore zapisivala na odvojene papire.

Pitanja su glasila: "Na koji način voliš provoditi svoje slobodno vrijeme s većom grupom vršnjaka?", potom "Na koji način voliš provoditi svoje slobodno vrijeme s bliskijim prijateljima?" te "Po čemu vidiš da je netko od tvojih vršnjaka odbačen?"

Dječje odgovore potom smo izbrojili te smo one s učestalošću većom od 5 uključili u skalu. Odgovori su se u velikom broju ponavljali, pa smo zaključili da većina učenika petih razreda na sličan način provodi slobodno vrijeme s vršnjacima. 
DRUŠ. ISTRAŽ. ZAGREB GOD. 21 (2012),

BR. $1(115)$

STR. 137-158

MARIČIĆ, J., KAMENOV, Ž., HORVAT, K.: PREDRASUDE U

\section{REZULTAT}

\section{Faktorska struktura dviju skala socijalne distance}

Provedene su analize glavnih komponenata za svaku od četiri "klasične" skale socijalne distance te za svaku od četiri skale socijalne distance vezane uz načine provođenja slobodnog vremena. Za određivanje broja značajnih komponenata prvo je upotrijebljen Kaiser-Guttmanov kriterij, koji je za svaku od skala rezultirao dvjema glavnim komponentama karakterističnoga korijena većeg od jedan, osim na skali socijalne distance vezanoj uz načine provođenja slobodnog vremena prema Romima, gdje je karakterističan korijen veći od jedan utvrđen samo za prvu komponentu. Drugi kriterij bio je Scree-test, na kojem je jasno istaknut jedan faktor, dok su ostali sa znatno nižim karakterističnim korijenima. Istaknutost jednoga faktora vidi se i na "klasičnim" skalama socijalne distance, no još je izraženija na skalama socijalne distance vezane uz načine provođenja slobodnog vremena, što je prikazano u Tablici 1. 
"Klasična" skala socijalne distance

Slijepa djeca

$\begin{array}{llll}3,52 & 1,32 & 0,60 & 0,55 \\ 3,52 & 1,22 & 0,63 & 0,57 \\ 3,69 & 1,34 & 0,59 & 0,48 \\ 3,92 & 1,13 & 0,68 & 0,42\end{array}$

Pretila djeca

Romska djeca

Skala socijalne distance vezane uz

načine provođenja slobodnog vremena

Slijepa djeca

Djeca u invalidskim kolicima

(1) TABLICA 1

Broj faktora na koje upućuju karakterističn korijeni na "klasičnim" skalama socijalne distance i na skalama socijalne distance vezane uz načine provođenja slobodnog vremena
Zbog utvrđene istaknutosti jednoga faktora, koja je u skladu s teorijskim očekivanjima da je socijalna distanca jednodimenzionalni konstrukt (Wark i Galliher, 2007.), odlučeno je da se kod svih skala zadrži samo jedan faktor. U tablicama prikazujemo faktorska opterećenja i komunalitete pojedinih čestica na tom zadržanome faktoru na "klasičnim" skalama socijalne distance (Tablica 2) te na skalama socijalne distance vezane uz načine provođenja slobodnog vremena (Tablica 3).



$\mathrm{h}^{2}=$ komunalitet

(1) TABLICA 2

Faktorska struktura te pouzdanost "klasičnih" skala socijalne distance uz zadržavanje jednoga faktora
Iz Tablice 2 vidi se da sve skale imaju visoku pouzdanost, a dodatnom analizom potvrđeno je da ni jedna od skala ne sadrži česticu koja bi smanjivala njezinu pouzdanost. Niske komunalitete na nekim skalama imaju prva ("da živi u tvojem gradu") i zadnja čestica ("da bude tvoj najbolji prijatelj").

Primjetno je da sve skale prikazane $u$ Tablici 3 imaju vrlo visoke pouzdanosti. Dodatnom analizom potvrđeno je da ni jedna čestica ne smanjuje pouzdanost skale. 


\begin{tabular}{|c|c|c|c|c|c|c|c|c|}
\hline $\begin{aligned} \text { Slijep } \\
\text { Faktc } \\
\text { rec }\end{aligned}$ & $\begin{array}{l}\text { pa djec } \\
\text { torska } \\
\text { opte- } \\
\text { ećenja }\end{array}$ & $h^{2}$ & $\begin{array}{r}\text { Djeca u inv } \\
\text { lidskim kol } \\
\text { Faktorska } \\
\text { opte- } \\
\text { rećenja }\end{array}$ & $\begin{array}{r}\text { cima } \\
\mathrm{h}^{2}\end{array}$ & $\begin{array}{r}\text { Pretila djec } \\
\begin{array}{r}\text { Faktorska } \\
\text { opte- } \\
\text { rećenja }\end{array}\end{array}$ & $h^{2}$ & $\begin{array}{r}\text { Romska dj } \\
\begin{array}{r}\text { Faktorska } \\
\text { opte- } \\
\text { rećenja }\end{array}\end{array}$ & $\mathrm{ca}$ \\
\hline $\begin{array}{l}\text { Da idemo na istu slobod- } \\
\text { nu aktivnost (npr. u kom- } \\
\text { pjutersku igraonicu, u mu- } \\
\text { zičku školu, na neki sport) }\end{array}$ & 0,55 & 0,32 & 0,38 & 0,16 & 0,55 & 0,31 & 0,62 & 0,39 \\
\hline $\begin{array}{l}\text { Da se zajedno vraća- } \\
\text { mo iz škole ako blizu } \\
\text { stanujemo }\end{array}$ & 0,70 & 0,51 & 0,63 & 0,40 & 0,68 & 0,46 & 0,77 & 0,60 \\
\hline $\begin{array}{l}\text { Da idem s njim u slobodno } \\
\text { vrijeme na školsko igralište }\end{array}$ & 0,74 & 0,54 & 0,73 & 0,53 & 0,76 & 0,58 & 0,79 & 0,63 \\
\hline $\begin{array}{l}\text { Da bude dio društva } \\
\mathrm{s} \mathrm{kojim} \mathrm{se} \mathrm{družim} \mathrm{ispred} \\
\text { zgrade ili u parku }\end{array}$ & 0,73 & 0,53 & 0,75 & 0,56 & 0,66 & 0,44 & 0,78 & 0,61 \\
\hline $\begin{array}{l}\text { Da zajedno idemo } \\
\text { u McDonald's, na pizzu } \\
\text { ili na sladoled }\end{array}$ & 0,73 & 0,52 & 0,67 & 0,45 & 0,66 & 0,43 & 0,82 & 0,68 \\
\hline $\begin{array}{l}\text { Da ga pozovem } \mathrm{k} \text { sebi na } \\
\text { tulum ili na rođendan }\end{array}$ & 0,77 & 0,58 & 0,66 & 0,44 & 0,71 & 0,51 & 0,82 & 0,68 \\
\hline $\begin{array}{l}\text { Da se često čujemo tele- } \\
\text { fonom ili dopisujemo }\end{array}$ & 0,70 & 0,48 & 0,70 & 0,49 & 0,76 & 0,58 & 0,79 & 0,62 \\
\hline $\begin{array}{l}\text { Da odem k njemu kući } \\
\text { kada me pozove }\end{array}$ & 0,73 & 0,53 & 0,68 & 0,46 & 0,68 & 0,46 & 0,80 & 0,64 \\
\hline $\begin{array}{l}\text { Da se često družimo } \\
\text { u mojoj kući }\end{array}$ & 0,80 & 0,65 & 0,81 & 0,66 & 0,76 & 0,58 & 0,80 & 0,64 \\
\hline $\begin{array}{l}\text { Da se svakodnevno } \\
\text { družimo }\end{array}$ & 0,76 & 0,58 & 0,76 & 0,58 & 0,76 & 0,58 & 0,75 & 0,57 \\
\hline $\begin{array}{l}\text { Da s njim razgovaram } \\
\text { o stvarima o kojima ne } \\
\text { razgovaram ni s kim } \\
\text { drugim (npr. o nekim } \\
\text { svojim tajnama) }\end{array}$ & 0,55 & 0,31 & 0,54 & 0,29 & 0,61 & 0,38 & 0,65 & 0,42 \\
\hline $\begin{array}{l}\text { Postotak objašnjene varijance } \\
\text { Pouzdanost skale }(\alpha)\end{array}$ & \multicolumn{2}{|c|}{50,17} & \multicolumn{2}{|c|}{45,32} & \multicolumn{2}{|c|}{48,12} & \multicolumn{2}{|c|}{58,46} \\
\hline
\end{tabular}

$\mathrm{h}^{2}=$ komunalitet

(1) TABLICA 3

Faktorska struktura ska-

la socijalne distance vezane uz načine provođenja slobodnog vremena uz zadržavanje jednoga faktora

Iako većina čestica na skalama socijalne distance vezane uz načine provođenja slobodnog vremena ima zadovoljavajuće visoke komunalitete, nezadovoljavajuće komunalitete imaju čestice koje se odnose na najudaljeniji oblik kontakta (polaženje iste slobodne aktivnosti) ili na najbliskiji oblik kontakta (pričanje o stvarima o kojima ne priča ni s kim drugim). 


\section{Stupanj neprihvaćanja pripadnika četiriju skupina}

Na Slici 1 su radi ilustracije utvrđenih obrazaca neprihvaćanja različitih skupina djece u kontekstu obuhvaćenih oblika kontakata prikazani postoci učenika koji ne prihvaćaju pojedini oblik kontakta. Uočljivo je da djeca iskazuju najveću socijalnu distancu prema Romima, dok značajno manju distancu iskazuju prema slijepoj djeci, djeci koja se kreću u invalidskim kolicima i prema pretiloj djeci (Slika 1).

$\rightarrow$ SLIKA 1

Postotak djece koja su izrazila neprihvaćanje pojedine skupine na svakoj od čestica "klasične" skale socijalne distance

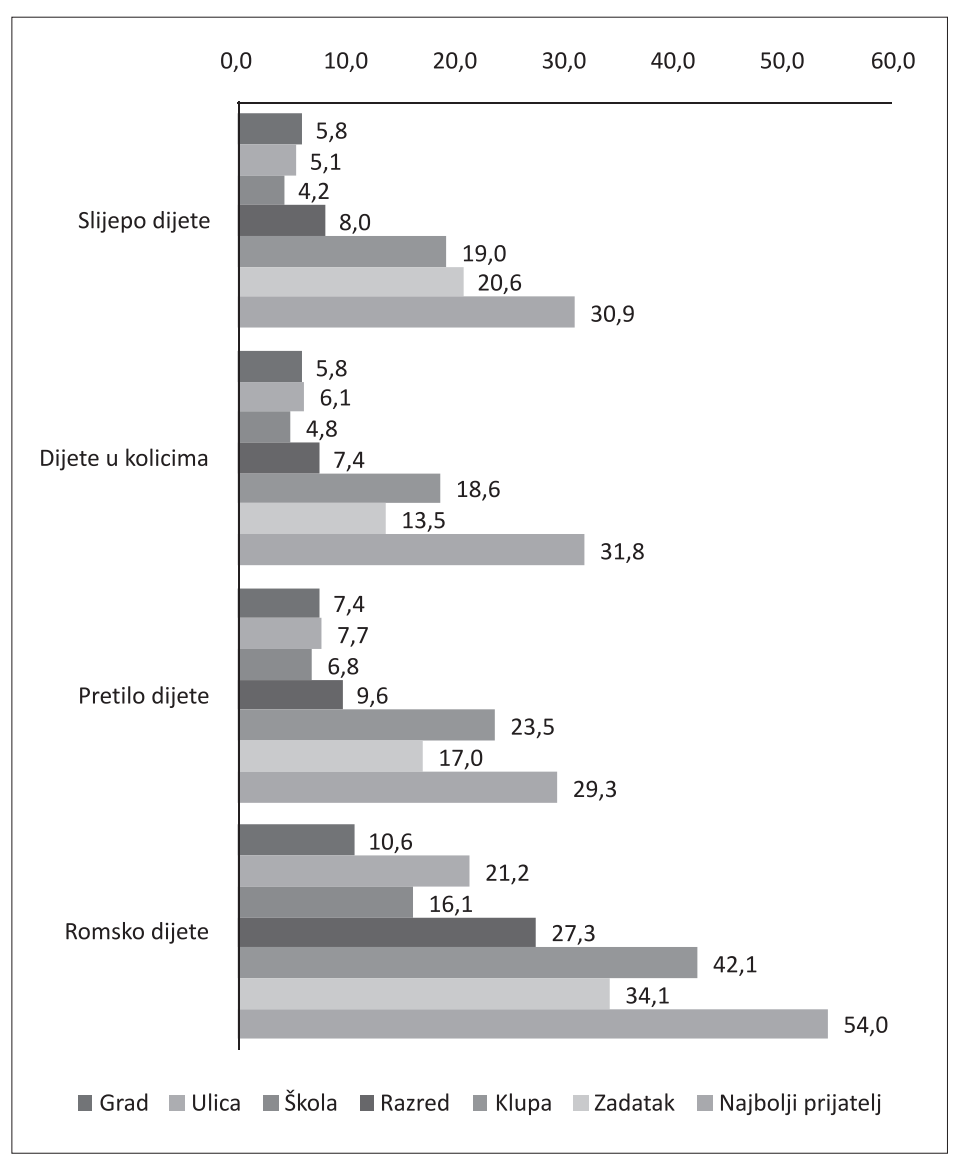

Više od desetine učenika ne prihvaća da Romi žive u njihovome gradu $(10,6 \%)$, dok ih više od petine ne prihvaća da žive u njihovoj ulici $(21,2 \%)$. Zanimljiv je nalaz da veći postotak djece ne prihvaća da Romi žive u njihovoj ulici nego da idu s njima u školu (16,1\%). Vjerojatno je to posljedica činjenice da je škola ipak formalna institucija, dok je ulica mjesto na kojem često provode slobodno vrijeme te na kojem ne žele nikoga "nepoželjnog".

Iz Slike 1 vidi se i to da bi više od 90\% djece prihvatilo da slijepo dijete, pretilo ili dijete $\mathrm{u}$ invalidskim kolicima boravi $\mathrm{u}$ njihovom gradu, ulici, školi ili razredu, dok se taj postotak zna- 
DRUŠ. ISTRAŽ. ZAGREB GOD. 21 (2012), BR. $1(115)$

STR. 137-158

MARIČIĆ, J., KAMENOV, Ž., HORVAT, K.: PREDRASUDE U čajno smanjuje kada se postavi pitanje o sjedenju u istoj klupi. Oblici krivulja nakon "polaženja istog razreda" nalik su krivulji za Rome, iako su vrijednosti niže. Dok u svim ranijim oblicima kontakta djeca mogu izbjeći interakciju s djetetom s određenim obilježjem, pri sjedenju u istoj klupi to nije moguće. Dakle, može se zaključiti da djeca gotovo uvijek prihvaćaju djecu s invaliditetom i onu s prekomjernom težinom dokle god ne moraju biti u izravnoj interakciji s njima.

Vidljivo je da je prihvaćanje triju skupina veće u odnosu na izvršavanje zajedničkoga zadatka nego na zajedničko sjedenje u klupi. Očekivani redoslijed bio je različit, jer je sjedenje u klupi percipirano kao moguće pasivno stanje, dok izvršavanje zajedničkoga zadatka nužno uključuje zajedničku aktivnost, pri čemu je, čini se, zanemareno da je sjedenje $u$ istoj klupi najčešće dugotrajno, dok je izvršavanje zajedničkoga zadatka kratkotrajno. Također je primjetno da je kod neprihvaćanja slijepe djece redoslijed tih dviju čestica obrnut od onoga za tri preostale skupine; djeci je manje prihvatljivo izvršavati zajednički zadatak sa slijepim djetetom nego sjediti s njim u klupi.

Neprihvaćanje pripadnika svih četiriju skupina kao najboljega prijatelja daleko je najizraženije; gotovo trećina djece ne bi prihvatila slijepo dijete, dijete u kolicima i pretilo dijete kao najboljega prijatelja, dok ih više od pola ne bi prihvatilo romsko dijete u tom svojstvu.

Podaci predočeni na Slici 2 upućuju na obrasce neprihvaćanja u slobodno vrijeme te predstavljaju svojevrsno proširenje čestice koja se odnosi na (ne)prihvaćanje prijateljstva; na temelju predočenih podataka može se uočiti koji su aspekti vršnjačkih i prijateljskih odnosa s djecom iz pojedinih skupina ostaloj djeci neprihvatljivi.

Ponovno je primjetna sklonost djece da u većoj mjeri prihvaćaju slijepu djecu, djecu u invalidskim kolicima i pretilu djecu nego djecu romske nacionalnosti. Stoga postoji povećana vjerojatnost da će se romska djeca osjećati odbačeno od svojih vršnjaka iz većinske skupine.

Iako je odbacivanje ostalih triju skupina znatno manje od odbacivanja Roma, ono je svejedno relativno visoko te zabrinjavajuće. Unatoč tomu što je djeci naglašeno da se usmjere na onu aktivnost unutar čestice koju djeca s određenim obilježjem mogu uspješno raditi, ipak je primjetno dječje odbacivanje povezano s aktivnostima u kojima očekuju da će djeca s određenim obilježjem biti slabija - primjerice, manji postotak djece prihvatio bi da slijepo dijete ide s njima na slobodnu aktivnost nego što bi prihvatio da ide s njima iz škole kući, ako blizu stanuju. 
DRUŠ. ISTRAŽ. ZAGREB GOD. 21 (2012) BR. 1 (115)

STR. $137-158$

MARIČIĆ, J., KAMENOV, Ž., HORVAT, K.: PREDRASUDE U

Kod pretile su djece, kao što je napomenuto u prikazu metode, sudionici već u prvom ispitivanju komentirali česticu "da ide s tobom u McDonald's, na pizzu ili na sladoled" na način da nije dobro za nekoga tko ima previše kilograma da ide na takva mjesta. Unatoč danom objašnjenju, ova čestica, te čestica "da idemo zajedno na školsko igralište" negativnije su procijenjene od ostalih čestica koje upućuju na udaljenije stupnjeve kontakta, što je vjerojatno posljedica konkretnih fizičkih karakteristika pretile djece.

\section{$\rightarrow$ SLIKA 2 \\ Postotak djece koja su izrazila neprihvaćanje poledine skupine na svakoj od čestica skale socijalne distance vezane uz načine provođenja slobodnog vremena}




\section{Spolne razlike u socijalnoj distanci}

(1) TABLICA 4

Postotak diečaka

djevojčica koji su

izrazili neprihvaćanje

na određenom broju

čestica na klasično

skali socijalne distance

Postojanje eventualnih značajnih razlika u socijalnoj distanci s obzirom na spol provjereno je $\chi^{2}$ testovima. Zbog maloga broja sudionika koji su iskazali neprihvaćanje na većem broju čestica, "klasična" skala socijalne distance rekodirana je tako da su svi sudionici koji su iskazali neprihvaćanje na 3 ili više čestica smješteni $u$ istu kategoriju.

\begin{tabular}{lllrrrr}
\hline & & \multicolumn{5}{c}{ Broj čestica na kojima je } \\
Procjenjivane skupine & Spol & 0 & 1 & 2 & $3-7$ & $\chi^{2}$ \\
\hline Slijepa djeca & djevojčice & 65,2 & 19,3 & 8,7 & 6,8 & $13,91^{* *}$ \\
& dječaci & 52,2 & 16,6 & 10,6 & 20,6 & \\
Djeca u invalidskim kolicima & djevojčice & 72,0 & 14,9 & 5,6 & 7,5 & \multirow{2}{*}{$19,16^{* *}$} \\
& dječaci & 50,0 & 18,0 & 13,3 & 18,7 & \\
Pretila djeca & djevojčice & 74,5 & 13,1 & 6,8 & 5,6 & \multirow{2}{*}{$32,56^{* *}$} \\
& dječaci & 48,0 & 13,3 & 12,7 & 26,0 & \\
Romska djeca & djevojčice & 46,0 & 18,0 & 8,1 & 27,9 & \multirow{2}{*}{$16,29^{* *}$} \\
& dječaci & 28,7 & 12,7 & 11,3 & 47,3 & \\
\hline
\end{tabular}

${ }^{* *} \mathrm{p}<0,01$

(1) TABLICA 5

Postotak diečaka i dievojčica koji su izrazili neprihvaćanje na određenom broiu čestica na skali socijalne distance vezanoj uz načine provođenja slobodnog vremena
Iz Tablice 4 vidi se da dječaci u prosjeku iskazuju neprihvaćanje pripadnika svih četiriju skupina na značajno većem broju čestica nego djevojčice, što je u skladu s ranije navedenim pretpostavkama.

Radi testiranja značajnosti eventualnih spolnih razlika na skalama socijalne distance vezanima uz načine provođenja slobodnog vremena $\chi^{2}$ testovima, provedeno je sažimanje kategorija. Tako su u jednu kategoriju svrstani svi sudionici koji su izrazili neprihvaćanje od 4 do 6 oblika kontakata, a u drugu sudionici koji su izrazili neprihvaćanje od 7 do 11 oblika kontakata. Na temelju svih drugih načina rekodiranja varijabli događalo se da u nekoj od kategorija na jednoj od skala bude 5 ili manje sudionika po ćeliji.

\begin{tabular}{|c|c|c|c|c|c|c|c|c|}
\hline \multirow[b]{2}{*}{ Procjenjivane skupine } & \multirow[b]{2}{*}{ Spol } & \multicolumn{6}{|c|}{$\begin{array}{l}\text { Broj čestica na kojima je } \\
\text { dijete iskazalo neprihvaćanje }\end{array}$} & \multirow[b]{2}{*}{$\chi^{2}$} \\
\hline & & 0 & 1 & 2 & 3 & $4-6$ & $7-11$ & \\
\hline Slijepa djeca & $\begin{array}{l}\text { djevojčice } \\
\text { dječaci }\end{array}$ & $\begin{array}{l}56,6 \\
39,3\end{array}$ & $\begin{array}{l}14,9 \\
15,3\end{array}$ & $\begin{array}{l}6,2 \\
4,7\end{array}$ & $\begin{array}{l}6,2 \\
8,0\end{array}$ & $\begin{array}{r}9,3 \\
18,0\end{array}$ & $\begin{array}{r}6,8 \\
14,7\end{array}$ & $14,28^{*}$ \\
\hline Djeca $\mathrm{u}$ invalidskim kolicima & $\begin{array}{l}\text { djevojčice } \\
\text { dječaci }\end{array}$ & $\begin{array}{l}54,7 \\
38,0\end{array}$ & $\begin{array}{l}13,7 \\
14,7\end{array}$ & $\begin{array}{r}11,8 \\
6,7\end{array}$ & $\begin{array}{l}6,8 \\
6,7\end{array}$ & $\begin{array}{r}8,7 \\
19,2\end{array}$ & $\begin{array}{r}4,3 \\
14,7\end{array}$ & $22,09^{* *}$ \\
\hline Pretila djeca & $\begin{array}{l}\text { djevojčice } \\
\text { dječaci }\end{array}$ & $\begin{array}{l}59,6 \\
35,3\end{array}$ & $\begin{array}{l}18,0 \\
16,0\end{array}$ & $\begin{array}{l}3,7 \\
7,3\end{array}$ & $\begin{array}{l}5,7 \\
8,7\end{array}$ & $\begin{array}{r}8,7 \\
18,7\end{array}$ & $\begin{array}{r}4,3 \\
14,0\end{array}$ & $26,39 * *$ \\
\hline Romska djeca & $\begin{array}{l}\text { djevojčice } \\
\text { dječaci }\end{array}$ & $\begin{array}{l}34,2 \\
20,0\end{array}$ & $\begin{array}{r}14,9 \\
8,0\end{array}$ & $\begin{array}{l}5,0 \\
4,0\end{array}$ & $\begin{array}{l}5,6 \\
8,0\end{array}$ & $\begin{array}{l}13,7 \\
18,7\end{array}$ & $\begin{array}{l}26,6 \\
41,3\end{array}$ & $15,86^{* *}$ \\
\hline
\end{tabular}

${ }^{*} \mathrm{p}<0,05,{ }^{* *} \mathrm{p}<0,01$ 
Iz Tablice 5 vidi se i to da dječaci i u bliskijim kontaktima u prosjeku iskazuju značajno veće neprihvaćanje prema pripadnicima svih četiriju skupina.

Cilj ovog istraživanja bio je konstruirati i provjeriti dva tipa skala socijalne distance za djecu te ispitati sklonost dječaka i djevojčica (ne)prihvaćanju pripadnika različitih skupina. Analizom glavnih komponenata potvrđena su teorijska očekivanja da se radi o jednodimenzionalnom konstruktu (Wark i Galliher, 2007.). Pritom treba napomenuti da su za pojedine čestice utvrđeni niski komunaliteti, međutim značajka konstrukta socijalne distance jest da prvi stupanj distance označuje oblik odnosa koji je samo rijetkim osobama neprihvatljiv. U tom smislu, ovaj tip čestica (da živi u tvojem gradu, da idete na istu slobodnu aktivnost), iako s niskim komunalitetima, važan je za skale socijalne distance jer upućuje na izrazitu sklonost odbacivanju, a pri eventualnom računanju ukupnog rezultata ne smanjuje pouzdanost. Kod polaženja iste slobodne aktivnosti nizak komunalitet djelomično se može pripisati i činjenici da dijete može u manjoj mjeri birati s kim će ići na istu slobodnu aktivnost nego s kim će se družiti na druge navedene načine.

Niži komunalitet dobiven je i na česticama koje označuju najveći stupanj bliskosti, jer se vežu uz odnos koji dijete može imati samo s manjim brojem najbliskijih osoba, pa je očekivano relativno najveće neprihvaćanje, odnosno donekle odstupanje od ostalih oblika kontakata.

Valja također imati na umu da je skala primijenjena na jedanaestogodišnjacima iz zagrebačkih škola, dok bi je trebalo dodatno provjeriti i u drugim dobnim skupinama ili regijama.

Drugi specifičan cilj istraživanja bio je utvrditi dječju sklonost (ne)prihvaćanju vršnjaka koji se kreću u invalidskim kolicima te slijepih, pretilih i vršnjaka romske nacionalnosti, uz postavljenu pretpostavku da će romska djeca biti manje prihvaćena nego djeca iz ostalih triju skupina. Ta se pretpostavka u većoj mjeri temelji na razvojnoj teoriji socijalnog identiteta (Nesdale, 1999.), koja naglašava važnost normi i emocija, nego na socijalnokognitivnoj teoriji razvoja predrasuda (Aboud, 1988.). Prema potonjoj teoriji, izraženost predrasuda prema različitim skupinama trebala bi biti slična i zato što je $u$ podlozi svih predrasuda potreba za kognitivnim pojednostavnjivanjem, koja se smanjuje s razvojem kognitivnih sposobnosti.

Dobiveni postoci odbacivanja, koji upozoravaju na najizraženiju sklonost odbacivanju romske djece, zaista u većoj mjeri potvrđuju razvojnu teoriju socijalnog identiteta nego socijalnokognitivnu teoriju razvoja predrasuda. U hrvatskom su društvu, naime, prisutne norme prema kojima je u redu odbi- 
DRUŠ. ISTRAŽ. ZAGREB GOD. 21 (2012), BR. 1 (115)

STR. 137-158

MARIČIĆ, J., KAMENOV, Ž., HORVAT, K.: PREDRASUDE U jati kontakt s Romima (Hrvatić, 1996.), dok nije u redu otvoreno odbijati kontakt $\mathrm{s}$ osobama s invaliditetom. Iako nalazi nekih stranih istraživanja (npr. Crandall i sur., 2009.; Puhl i Brownell, 2001.) upućuju na normu da je u redu iskazivati predrasude prema pretilima, stupanj iskazane socijalne distance prema pretiloj djeci približno je podjednak socijalnoj distanci prema djeci s raznim invaliditetima.

Razlozi odbacivanja Roma višestruki su - od drugačijega fizičkog izgleda, marginalne socioekonomske, obrazovne i ukupne društvene pozicije, do uobičajenih tradicionalnih predrasuda prema toj etničkoj skupini (Babić, 2004.). Nalaz da je u odnosu na etničku pripadnost socijalna distanca najprisutnija prema Romima ranije je dobiven na adolescentima $\mathrm{u} \mathrm{Hr}$ vatskoj (Hrvatić, 2004.; Previšić i sur., 2004.; Hrvatić, 1996.) te na djeci u Srbiji (Mihić i Mihić, 2003.). Djeca su općenito sklona izražavati snažnije etničke predrasude nego odrasli (npr. Mihić i Mihić, 2003.; Čorkalo Biruški i Ajduković, 2008.). Mihić i Mihić (2003.) navode dva moguća objašnjenja za to; prvo je da djeca odgovaraju iskreno, dok su roditelji suzdržani, a drugo je da na dječju etničku distancu utječu i neki drugi čimbenici, poput veće emocionalnosti djece. Ujedno, moguće je da su djeca prilikom odgovaranja bila pod utjecajem stereotipa o Romima kao o prljavima i devijantnima (Babić, 2004.). Dakle, romska djeca mogu biti izložena dvostrukom riziku; jednom koji proizlazi iz negativnih stereotipa o njima i drugom koji proizlazi iz samog iskustva odbacivanja, što povećava vjerojatnost razvoja rizična i neprilagođena ponašanja (Parker i Asher, 1987.).

Socijalno odbacivanje drugih triju skupina u našem istraživanju nije toliko drastično kao odbacivanje romske djece, no također upućuje na potrebu intervencija s ciljem boljega prihvaćanja djece s tim obilježjima. Nalazi o dječjim predrasudama prema pretiloj djeci raznoliki su: primjerice, Penny i Haddock (2007.) pronašli su da su djeca od 9 i 10 godina jednako često procijenila da fiktivno pretilo dijete ima dobre akademske i umjetničke sposobnosti kao i dijete prosječne težine te da su ga čak procijenila socijalno sposobnijim od djeteta prosječne težine. Neki drugi autori (npr. Hansson i sur., 2009.) navode da djeca pretile likove procjenjuju kao spore, lijene, osamljene i drugačije, no i kao ljubazne i vesele. Na neugodne socijalne posljedice upozoravaju Strauss i Pollack (2003.), koji su pronašli da pretili adolescenti češće u socijalnim mrežama zauzimaju periferna mjesta, te Lagerspetz i sur. (1982.), koji su utvrdili da pretilo dijete ima 15 puta veću vjerojatnost od vitkoga da će ga vršnjaci maltretirati. Iako nalazi ovog istraživanja ne upućuju na izrazitiju isključenost pretile djece, treba napomenuti da i manji stupanj isključivanja može imati negativne posljedice. Primjerice, već i to da djeca učestalije ne 
DRUŠ. ISTRAŽ. ZAGREB GOD. 21 (2012), BR. 1 (115)

STR. 137-158

MARIČIĆ, J., KAMENOV, Ž., HORVAT, K.: PREDRASUDE Ü. žele sa svojim pretilim vršnjakom ići na javno mjesto gdje se jede može dovesti do smanjenja socijalnih kontakata.

Što se tiče odnosa prema djeci s invaliditetom, pokazalo se da se odbacivanje pojavljuje "tek" u najbliskijim oblicima kontakta, poput rada na zajedničkom zadatku ili sjedenja u istoj klupi. To je u skladu s nalazima istraživanja Leutar (2003.), prema kojima $81,2 \%$ djece u školi bez integracije i $88,0 \%$ djece u školi s integracijom odgovara da bi se željela družiti s djecom s invaliditetom, međutim oko $10 \%$ manje u obje škole odgovara da bi željelo sjediti u klupi s djetetom s invaliditetom. Ovi nalazi upućuju i na to da iskustvo integracije donekle smanjuje predrasude, što potvrđuje i Hazzard (1983.). Ladd i sur. (1984.) proveli su istraživanje na gluhim srednjoškolcima koji su bili integrirani na početku srednje škole. Velika većina i gluhih i čujućih navela je da u školi imaju prijatelja iz druge skupine. Ipak, intervjui s roditeljima i nastavnicima pokazali su da se te dvije skupine rijetko druže izvan škole.

Na pitanje zbog čega se ne bi željela družiti s djecom s invaliditetom, djeca odgovaraju da ne znaju kako bi im pristupila, da se boje da ih neće razumjeti te da će u susretu s njima biti zbunjena (Leutar, 2003.). Zabrinjavajuće je što ni prihvaćanje kontakta ne znači nužno izostanak predrasude; naime, najčešći odgovor na pitanje zbog čega bi djeca željela sjediti s djetetom s invaliditetom jest taj da su djeca s invaliditetom bespomoćna pa bi im ona željela pomagati (Leutar, 2003.). Longoria i Marini (2006.) zaključuju da su djeca školske dobi uglavnom sposobna razlikovati funkcionalne sposobnosti osoba s invaliditetom, no da su, unatoč tome sklona vidjeti takvo dijete kao značajno pasivnije te procijeniti da dijete koje se kreće $u$ invalidskim kolicima većinu vremena provodi gledajući televiziju i pišući zadaću (Longoria i Marini, 2006.). Nalazi ovog istraživanja, prema kojima bi djeca češće odbila surađivati sa slijepim djetetom na zadatku za školu nego sjediti s njime u klupi, upućuju na moguću prisutnost fenomena "proširivanja", odnosno očekivanje da slijepa djeca vjerojatno ne bi mogla značajno pridonijeti zajedničkom zadatku. Medijski prikazi osoba s invaliditetom također često pogoduju predrasudama (Shapiro, 1999.). Primjerice, u nekim crtanim filmovima slabovidni likovi prikazani su kao prikladne mete za ismijavanje - oni se sudaraju, padaju, ispričavaju se predmetima koje udare u prolazu i slično. Time se kod djece sugerira zaključak da su osobe s oštećenjem vida nesposobne i nespretne te manje inteligentne (Shapiro, 1999.). Jedan od fenomena koji može utjecati na odbacivanje osoba s invaliditetom jest infantiliziranje, pri kojem se takvim osobama pridaju osobine te se prema njima ponaša kao da su osjetno mlađe (Gouvier i sur., 1994.; Liesener i Mills, 1999.; Robey i sur., 2006.). Primjerice, Gobo (2008.) navodi primjer osoblja 
DRUŠ. ISTRAŽ. ZAGREB GOD. 21 (2012), BR. 1 (115)

STR. 137-158

MARIČIĆ, J., KAMENOV, Ž., HORVAT, K.: PREDRASUDE U škole koje je na infantilizirajući način tretiralo slijepu djevojčicu te time drugoj djeci poručivalo da se ta djevojčica i socijalno, a ne samo fizički, razlikuje od njih. Potrebno je podrobnije ispitati dječje stereotipe kako bi se vidjelo koji su od njih najučestaliji te koji uzrokuju neprihvaćanje djece s invaliditetom.

Jedan od specifičnih ciljeva istraživanja bio je utvrditi postoje li spolne razlike u socijalnoj distanci prema različitim skupinama. Iako su spolne razlike u ovom istraživanju jasno potvrđene, rezultati drugih istraživanja u tom pogledu nisu jednoznačni; u nekima su se djevojčice pokazale nešto sklonijima pozitivnim stavovima prema osobama s invaliditetom (Hazzard, 1983.; Longoria i Marini, 2006.), kao i manjoj etničkoj distanci (Mihić i Mihić, 2003.); u drugima pak djevojčice na nekim mjerama pokazuju manju sklonost predrasudama, dok na drugima nema značajne razlike (Powlishta i sur., 1994.). Fishbein (2002.) zaključuje da su dječaci ili jednako skloni predrasudama kao i djevojčice ili pak da su skloniji predrasudama od djevojčica. Vjerojatno se radi o razlikama u primijenjenim mjerama te o tome koliko su mjere pod utjecajem onoga što se smatra socijalno poželjnim za pripadnike određenoga spola; primjerice, djevojčice su češće socijalizirane tako da trebaju prihvaćati i brinuti se za ljude oko sebe, što vjerojatno dovodi do njihove manje sklonosti socijalnoj distanci (Hazzard, 1983.; Mihić i Mihić, 2003.; Powlishta i sur., 1994.), dok nisu toliko socijalizirane u pogledu preferencije vlastite ili vanjske grupe, što vjerojatno rezultira sličnijim rezultatima djevojčica i dječaka na tom tipu mjera (npr. Fox i Jordan, 1973.; Goldstein i sur., 1979.; Powlishta i sur., 1994.).

Jedan od temeljnih nedostataka mjera socijalne distance, a time i ovog istraživanja, jest taj što je pripadnost grupi jedino obilježje koje sudionik zna o osobi koju treba prihvatiti ili odbaciti. Time je pripadnost grupi izrazito istaknuta, što može potencirati izražavanje predrasuda. Potvrdu toga da personifikacija pripadnika skupine smanjuje predrasude pružaju nalazi istraživanja Katz i Zalk (1978.), u kojem se učinkovitom za suzbijanje predrasuda pokazala intervencija tijekom koje su djeca, polaznici drugog i petog razreda osnovne škole, trebala naučiti imena različitih pripadnika iste grupe.

Među ostale prijetnje valjanosti ovog istraživanja možemo ubrojiti nereprezentativan uzorak, koji je posljedica neprobabilističkog odabira škola i činjenice da neka djeca u ispitivanim razredima, zbog nepotpisane roditeljske suglasnosti, nisu sudjelovala $u$ istraživanju. Stoga utvrđene postotke neprihvaćanja pojedinih oblika socijalnih kontakata treba tumačiti tek kao ilustraciju razlika u neprihvaćanju pojedinih skupina odnosa pojedinih oblika kontakata, a ne kao pokazatelj udjela djece koja neprihvaćaju pojedine kontakte s pripadnicima obuhvaćenih skupina. 
DRUŠ. ISTRAŽ. ZAGREB GOD. 21 (2012), BR. 1 (115)

STR. 137-158

MARIČIĆ, J., KAMENOV, Ž., HORVAT, K.: PREDRASUDE U

\section{ZAKLJUČAK}

\section{LITERATURA}

Budući da je jedan od nedostataka skala socijalne distance isticanje samo jedne, i to stigmatizirajuće, značajke osobe, $\mathrm{u}$ budućim bi istraživanjima trebalo umanjiti istaknutost te značajke, koristeći se, primjerice, identičnim pričama, u kojima lik u eksperimentalnoj skupini ima stigmatizirajuće obilježje, dok ga u kontrolnoj skupini nema. Također, pri eventualnim budućim primjenama treba voditi računa o utvrđenom redoslijedu čestica koji u pojedinim slučajevima odstupa od očekivanog.

Budući da se primijenjenim skalama može ispitivati socijalna distanca prema djeci s bilo kojim obilježjem, one se mogu rabiti i za istraživanja novijih oblika predrasuda - poput predrasuda prema fizički manje privlačnoj djeci ili prema djeci iz različitih "neprosječnih" obitelji. Ujedno, u budućim istraživanjima trebalo bi provjeriti povezanost između dječje sklonosti socijalnoj distanci i različitih obilježja i iskustava djece, kao što su osobine ličnosti, socioekonomski status obitelji, osobna iskustva odbačenosti ili ranija iskustva s osobama sa stigmatizirajućim obilježjima.

Istraživanjem je potvrđena jednodimenzionalnost dviju skala socijalne distance te mogućnost njihove primjene za mjerenje dječje socijalne distance prema drugoj djeci iz različitih skupina. Od skupina obuhvaćenih ovim istraživanjem djeca su iskazala najveću distancu prema Romima, dok su značajno manju, no ipak zabrinjavajuću, distancu iskazala i prema slijepoj djeci, djeci u invalidskim kolicima i pretiloj djeci. Posebno je problematična sklonost odbacivanju vršnjaka s navedenim obilježjima tijekom slobodnog vremena te izraženija sklonost socijalnoj distanci kod dječaka.

Aboud, F. E. (1988.), Children and Prejudice, Cambridge, MA, Basil Blackwell.

Aboud, F. E. i Levy, S. R. (2000.), Intervention to Reduce Prejudice and Discrimination in Children and Adolescents. U: S. Oskamp (ur.), Reducing Prejudice and Discrimination (str. 269-293), Mahwah, NJ, Lawrence Erlbaum Associates, Inc.

Babić, D. (2004.), Stigmatizacija i identitet Roma - pogled "izvana": slučaj učenika Roma u naselju Kozari Bok. Migracijske i etničke teme, 20 (4): 315-338.

Banovac, B. i Boneta, Ž. (2006.), Etnička distanca i socijalna (dez)integracija lokalnih zajednica. Revija za sociologiju, 37 (1-2): 21-46.

Bogardus, E. S. (1925.), Measuring Social Distance. Journal of Applied Sociology, 9: 299-308. Preuzeto 22. 8. 2010. sa stranice http://www. brocku.ca/MeadProject/Bogardus/Bogardus_1925c.html 
DRUŠ. ISTRAŽ. ZAGREB GOD. 21 (2012), BR. 1 (115)

STR. 137-158

MARIČIĆ, J., KAMENOV Ž., HORVAT, K.: PREDRASUDE U...
Crandall, C. S., Nierman, A. i Hebl, M. (2009.), Anti-Fat Prejudice. U: T. D. Nelson (ur.), Handbook of Prejudice, Stereotyping, and Discrimination (str. 469-487), New York, Psychology Press.

Čorkalo Biruški, D. i Ajduković, D. (2008.), Stavovi učenika, roditelja i nastavnika prema školovanju: što se promijenilo tijekom šest godina u Vukovaru? Migracijske i etničke teme, 24 (3): 189-216.

Čorkalo, D. i Kamenov, Ž. (2003.), National Identity and Social Distance: Does In-Group Loyalty Lead to Outgroup Hostility? Review of Psychology, 10 (2): 85-94.

Dovidio, J. F., Major, B. i Crocker, J. (2000.), Stigma: Introduction and Overview. U: T. F. Heatheron, R. E. Kleck, M. R. Hebl i J. G. Hull (ur.), The Social Psychology of Stigma (str. 1-28), London, The Guilford Press.

Fishbein, H. D. (2002.), Peer Prejudice and Discrimination: The Origin of Prejudice, Mahwah, NJ, Lawrence Erlbaum Associates, Inc.

Fox, D. J. i Jordan, V. B. (1973.), Racial Preference and Identification of Black, American Chinese, and White Children. Genetic Psychology Monographs, 88: 229-286.

Gobo, G. (2008.), Crafting Blindness: Its Organizational Construction in a First Grade School. Qualitative Sociology Review, 4 (1): 92-108.

Goldstein, C. G., Koopman, E. J. i Goldstein, H. H. (1979.), Racial Attitudes in Young Children as a Function of Interracial Contact in the Public Schools. The American Journal of Orthopsychiatry, 49 (1): 89-99. doi:10.1111/j.1939-0025.1979.tb02589.x

Gouvier, W., Coon, R., Todd, M. i Fuller, K. (1994.), Verbal Interactions with Individuals Presenting with and without Physical Disability. Rehabilitation Psychology, 39 (4): 263-268. doi:10.1037//0090-5550.39.4.263

Grgić, N. (2006.), Ispitivanje izraženosti predrasuda prema Romima, Diplomski rad, Zagreb, Filozofski fakultet u Zagrebu.

Hansson, L. M., Karnehed, N., Tynelius, P. i Rasmussen, F. (2009.), Prejudice Against Obesity among 10-Year-Olds: A Nationwide Population-Based Study. Acta Paediatrica, 98: 1176-1182.

Harris, M. B., Harris, R. J. i Bochner, S. (1982.), Fat, Four-Eyed, and Female: Stereotypes of Obesity, Glasses, and Gender. Journal of Applied Social Psychology, 12 (6): 503-516. doi:10.1111/j.1559-1816.1982. tb00882.x

Hazzard, A. (1983.), Children's Experience With, Knowledge of, and Attitude toward Disabled Persons. Journal of Special Education, 17 (2): 131-139. doi:10.1177/002246698301700204

Henderson, H. i Bryan, W. (1997.), Psychosocial Aspects of Disability, Springfield, IL, Charles C. Thomas.

Hill, T., Lewicki, P., Czyzewska, M. i Boss, A. (1989.), Self-Perpetuating Development of Encoding Biases in Person Perception. Journal of Personality and Social Psychology, 57 (3): 373-387. doi:10.1037//00223514.57.3.373

Hrvatić, N. (2004.), Romi u Hrvatskoj: od migracija do interkulturalnih odnosa. Migracijske i etničke teme, 20 (4): 467-385.

Hrvatić, N. (1996.), Romi u interkulturalnom okružju. Društvena istraživanja, 5 (5-6): 913-933. 
DRUŠ. ISTRAŽ. ZAGREB GOD. 21 (2012) BR. 1 (115),

STR. 137-158

MARIČIĆ, J., KAMENOV, Ž., HORVAT, K.: PREDRASUDE Ü.
Jokić-Begić, N., Kamenov, Ž. i Korajlija, L. (2005.), Kvalitativno i kvantitativno ispitivanje sadržaja stigme prema psihičkim bolesnicima. Socijalna psihijatrija, 33 (1): 10-19.

Kamenov, Ž. i Čorkalo, D. (1997.), Mjerenje promjena nacionalnih stereotipa: primjena metode SYMLOG-a. Društvena istraživanja, 6 (2-3): 361-372.

Katz, P. A. i Zalk, S. R. (1978.), Modification of Children's Racial Attitudes. Developmental Psychology, 14 (5): 447-461. doi:10.1037//00121649.14.5.447

Ladd, G., Munson, H. i Miller, J. (1984.), Social Integration of Deaf Adolescents in Secondary-Level Mainstreamed Programs. Exceptional Children, 50 (5): 420-428.

Lagerspetz, K. M., Björkqvist, K., Berts, M. i King, E. (1982.), Group Aggression among School Children in Three Schools. Scandinavian Journal of Psychology, 23 (1): 45-52. doi:10.1111/j.1467-9450.1982. tb00412.x

Leutar, Z. (2003.), Odnos vršnjaka prema djeci s invaliditetom. Hrvatska revija za rehabilitacijska istraživanja, 39 (2): 233-244.

Leutar, Z. i Štambuk, A. (2006.), Stavovi mladih prema osobama s tjelesnim invaliditetom. Revija za sociologiju, 37 (1-2): 91-102.

Liesener, J. J. i Mills, J. (1999.), An Experimental Study of Disability Spread: Talking to an Adult in a Wheelchair Like a Child. Journal of Applied Social Psychology, 29 (10): 2083-2092. doi:10.1111/j.1559-1816. 1999.tb02296.x

Longoria, L. i Marini, I. (2006.), Perception of Children's Attitudes towards Peers with a Severe Physical Disability. Journal of Rehabilitation, 72 (3): 19-25.

McWhirter, B. T. (1990.), Loneliness: A Review of Current Literature with Implications for Counseling and Research. Journal of Counseling and Development, 68 (4): 417-422. doi:10.1002/j.1556-6676.1990.tb02521.x

Mihić, V. i Mihić, I. (2003.), Poznajem, prihvatam, poštujem - istraživanje etničke distance kod dece i njihovih roditelja. Psihologija, 36 (2): 167-182.

Nesdale, D. (1999.), Social Identity and Ethnic Prejudice in Children. U: P. Martin i W. Noble (ur.), Psychology and Society (str. 92-110), Brisbane, Australian Academic Press.

Norden, M. F. (1994.), The Cinema of Isolation: A History of Physical Disabilities in the Mouvies, New Brunswick, NJ, Rutgers University Press.

Parker, J. G. i Asher, S. R. (1987.), Peer Relations and Later Personal Adjustment: Are Low-Accepted Children at Risk? Psychological Bulletin, 102 (3): 357-389. doi:10.1037//0033-2909.102.3.357

Penny, H. i Haddock, G. (2007.), Children's Stereotypes of Overweight Children. British Journal of Developmental Psychology, 25 (3): 409-418. doi:10.1348/026151006X158807

Powlishta, K. K., Serbin, L. A., Doyle, A.-B. i White, D. R. (1994.), Gender, Ethnic, and Body Type Biases: The Generality of Prejudice in Childhood. Developmental Psychology, 30 (4): 526-536. doi:10.1037// 0012-1649.30.4.526 
DRUŠ. ISTRAŽ. ZAGREB GOD. 21 (2012), BR. 1 (115)

STR. 137-158

MARIČIĆ, J., KAMENOV Ž., HORVAT, K.: PREDRASUDE U
Previšić, V., Hrvatić, N. i Posavec, K. (2004.), Socijalna distanca prema nacionalnim ili etničkim i religijskim skupinama. Pedagogijska istraživanja, 1 (1): 105-120.

Puhl, R. i Brownell, K. D. (2001.), Bias, Discrimination, and Obesity. Obesity Research, 9: 788-805. doi:10.1038/oby.2001.108

Robey, K. L., Beckley, L. i Kirschner, M. (2006.), Implicit Infantilizing Attitudes about Disability. Journal of Developmental and Physical Disabilities, 18 (4): 441-453. doi:10.1007/s10882-006-9027-3

Rutland, A., Cameron, L., Milne, A. i McGeorge, P. (2005.), Social Norms and Self-Presentation: Children's Implicit and Explicit Intergroup Attitudes. Child Development, 76 (2): 451-466. doi:10.1111/j.1467-8624. 2005.00856.x

Shapiro, A. (1999.), Everybody Belongs: Changing Negative Attitudes toward Classmates with Disabilities, London, Routledge.

Smith, L. A. i Williams, J. M. (1999.), Children's Understanding of the Physical, Cognitive and Social Consequences of Impairments. Child: Care, Health and Development, 27 (6): 603-617.

Strauss, R. S. i Pollack, H. A. (2003.), Social Marginalization of Overweight Children. Archives of Pediatric and Adolescent Medicine, 157 (8): 746-752. doi:10.1001/archpedi.157.8.746

Wark, C. i Galliher, J. F. (2007.), Emory Bogardus and the Origins of the Social Distance Scale. American Sociologist, 38 (4): 383-395. doi:10. 1007/s12108-007-9023-9

\section{Prejudice in Childhood: Validation of Two Social Distance Scales}

\author{
Jelena MARIČIĆ \\ Institute of Social Sciences Ivo Pilar, Zagreb \\ Želika KAMENOV \\ Faculty of Humanities and Social Sciences, Zagreb \\ Kristina HORVAT \\ Orehovica Elementary School, Orehovica
}

The aim of this research was to study children's prejudice. We administered children's social distance scales to $311 \mathrm{fifth}$ graders from 6 elementary schools in Zagreb. One of the scales measured willingness to engage in more or less distanced forms of contact (from living in the same town to forming close friendships), while the other measured willingness to spend leisure time through doing various activities with peers who had some specific characteristic. Target groups were blind children, children who use a wheelchair, obese children and Romani children. Factor analysis on both measures for every group produced meaningful one factor solutions. On both instruments children expressed the highest prejudice toward Romani children, while social distances toward the other three groups 
DRUŠ. ISTRAŽ. ZAGREB GOD. 21 (2012) BR. 1 (115)

STR. $137-158$

MARIČIĆ, J., KAMENOV, Ž., HORVAT, K.: PREDRASUDE U were similar. Boys constantly showed higher social distances than girls. There were also relatively high correlations between social distances toward the same groups on different instruments. The results generally indicate children's tendency to reject members of different groups and accentuate the necessity for interventions during preadolescence.

Keywords: children's prejudice, social distance, social rejection, persons with disabilities, obese persons, Roma 